\title{
Pelatihan manajemen keuangan sederhana bagi UKM di Kecamatan Benai, Kabupaten Kuantan Singingi
}

\author{
Ruzikna ${ }^{*} *$, Lie Othman, Lena Farida, dan Frini Karina Andini \\ Universitas Riau \\ * ruzikna67@gmail.com
}

\begin{abstract}
Abstrak. Potensi UKM hingga sejauh ini, belum cukup tergarap dengan maksimal, sebaliknya banyak pelaku usaha UKM (pemilik) justru sering mengalami masalah internal sehingga sulit untuk berkembang dan bersaing baik antara sesama UKM maupun dengan dengan produsen besar. Hal ini berkaitan dengan masalah pengelolaan keuangan yang menjadi salah satu masalah yang sering ditemui di dalam UKM. Umumnya, pelaku kegiatan ini memulai usaha mereka dengan bermodal nekat tanpa dibekali dengan rencana pemodalan jangka panjang maupun kemampuan dan pengetahuan manajerial yang dibutuhkan dalam berwirausaha. Pelatihan ini bertujuan agar masyarakat atau pelaku UKM di Kabupaten Kuantan Singingi dapat mengoptimalkan usahanya serta dapat mengembangkan usahanya untk meningkatkan perekonomian masyarakat. Dengan adanya pelatihan ini masyarakat menjadi dapat mengeola keuangan usahanya, serta mampu bersaing dengan produsen yang lebih besar nantinya. Kegiatan ini dilakukan dengan model ceramah, diskusi, serta mempraktikkan secara langsung praktik penyusunan laporan keuangan. Kegiatan ini juga terbuka untuk sharing permasalahan yang dihadapi UKM di Kabupaten Kuansing, sehingga nantinya akan memperoleh solusi atas permasalahan yang terjadi. Adapun hasil yang diperoleh dari pelatihan ini adalah peningkatan pengetahuan dan kemampuan pelaku usaha dalam menyusun laporan keuangan sehingga dapat mengembangkan UKM masyarakat dan berujung pada peningkatan pereknomian dan kesejahteraan masyarakat.
\end{abstract}

Kata kunci: UKM; potensi UKM; manajemen laporan keuangan; pengembangan usaha

Abstract. SME (Small Medium Entreprise) potentials to this extent, not enough to be able to maximum, otherwise many businesses SMES (owners) often have internal problems so it is difficult to develop and compete both between SMES and with the big producers. This relates to the problem of financial management which is one of the problems often encountered in SMES. Generally, the perpetrators of this activity start their efforts by having a reckless capital without being equipped with long-term capitalization plans as well as managerial skills and knowledge needed in entrepreneurship. This training aims to make the community or people of SMES in Kuantan Singingi District can optimize its business and can develop its business to improve the community economy. With this training the community becomes able to finance its business, as well as able to compete with larger producers later. This activity is conducted with a lecture model, discussion, and practice directly to prepare financial statements. This activity is also open to share problems faced by SMES in Kuansing District, so it will get solutions to the problems that occur. The results gained from this training are the increase in knowledge and ability of business actors to develop financial statements so that they can improve community SMES and lead to the improvement of the development and welfare of society.

Keywords: SME; SME potential; financial management; business development

To cite this article: Ruzikna, L. Othman, L. Farida, \& F. K. Andini. 2019. Pelatihan manajemen keuangan sederhana bagi UKM di Kecamatan Benai, Kabupaten Kuantan Singingi. Unri Conference Series: Community Engagement 1: 144-149. https://doi.org/10.31258/unricsce.1.144-149

(C) 2019 Authors

Peer-review under responsibility of the organizing committee of Seminar Nasional Pemberdayaan Masyarakat 2019 


\section{PENDAHULUAN}

Provinsi Riau dengan 12 Kabupaten/Kota dan memiliki luas 87.023,66 km² ini merupakan salah satu provinsi terkaya di Indonesia, dan sumber dayanya didominasi oleh sumber alam, terutama minyak bumi, gas alam, karet, kelapa sawit dan perkebunan serat. Provinsi yang kaya akan sumber daya alam yang berlimpah ini, memiliki jumlah penduduk sebanyak 6.500 .971 orang penduduk (www.bps.go.id).

Usaha Kecil dan Mikro, (UKM) merupakan usaha yang bermodalkan kurang lebih atau sama dengan Rp 200.000.000, sering disebut sebagai tulang punggung perekonomian Indonesia mengingat jumlahnya yang banyak Indonesia. Pada tahun 2018, jumlah UKM di seluruh Indonesia mencapai 56,5 juta dengan kontribusi kepada PDB sebesar 30\%. UKM merupakan sektor usaha yang paling banyak menyerap tenaga kerja di Indonesia hingga mencapai 97\% tenaga kerja Indonesia.

UKM di Provinsi Riau berkembang sangat cepat bila dibandingkan dengan kabupaten dan kota lainnya di Provinsi Riau. Hal ini dikarenakan Pekanbaru telah menjadi sebuah kota metropolitan, yang diwarnai dengan banyaknya para pelaku bisnis di sektor UKM. Berdasarkan data yang diperoleh dari Kota Pekanbaru dalam angka tahun 2014 (BPS Kota Pekanbaru) diperoleh gambaran sebagai berikut :

Tabel 1. Jumlah UKM di Provinsi Riau tahun 2014-2018

\begin{tabular}{clccccc}
\hline No & \multicolumn{1}{c}{ Kabupaten/Kota } & 2014 & 2015 & 2016 & 2017 & 2018 \\
\hline 1 & Pelalawan & 21.300 & 21.300 & 21.548 & 21.633 & 21.633 \\
2 & Indragiri Hilir & 54.522 & 54.522 & 54.584 & 54.584 & 54.584 \\
3 & Kampar & 53.059 & 53.059 & 53.147 & 53.307 & 53.307 \\
4 & Rokan Hilir & 38.686 & 38.686 & 39.319 & 39.319 & 39.319 \\
5 & Siak & 30.994 & 30.994 & 31.157 & 31.183 & 31.183 \\
6 & Kabupaten. Bengkalis & 39.300 & 39.300 & 39.406 & 39.573 & 46.727 \\
7 & Meranti & 10.898 & 10.898 & 11.016 & 11.016 & 11.016 \\
8 & Pekanbaru & 93.095 & 93.095 & 93.161 & 93.161 & 93.161 \\
9 & Kuantan Singingi & $\mathbf{2 8 . 7 3 5}$ & $\mathbf{2 8 . 7 3 5}$ & $\mathbf{2 9 . 0 8 8}$ & $\mathbf{2 9 . 0 8 8}$ & $\mathbf{3 0 . 4 1 0}$ \\
10 & Dumai & 39.398 & 39.398 & 39.497 & 45.135 & 45.363 \\
11 & Indragiri Hulu & 33.335 & 36.280 & 36.322 & 71.757 & 71.757 \\
12 & Rokan Hulu & 35.926 & 35.926 & 36.044 & 36.044 & 36.044 \\
\hline & Total & 479.248 & 482.193 & 484.289 & 525.800 & 534.504 \\
\hline
\end{tabular}

Berdasarkan table diatas, dapat dilihat angka perkembangan UKM di Provinsi Riau yang terus meningkat dari tahun ke tahun. Begitu juga dengan Kabuaten Kuantan Singingi yang menjadi focus pengabdian ini, jumlah UKM yang dimiliki mengalami pengingkatan pada 4 tahun terakhir. Kabupaten ini memiliki luas wilayah 7.656,03 km², dengan jumlah penduduk 317.935 jiwa, dan 15 kecamatan, yaitu Kecamatan Benar, Cerenti, Gunung Toar, Inuman, Hulu Kuantan, Kuantan Hilir, Kuantan Hilir Seberang, Kuantan Mudik, Kuantan Tengah, Logas Tanah Datar, Pangean, Pucuk Rantau, Sentajo Raya, Singingi dan Singingi Hilir (www.bps.go.id).

Berdasarkan survey awal tim dan data dari Dinas Perindustrian Kabupaten Kuantan Singingi, masyarakat memiliki berbagai jenis usaha UKM yang menjual produk dari hasil pertanian atau potensi yang dimiliki setiap desa. Adapun jenis usaha yang mereka miliki seperti usaha wajik takiak, wajik lopur, kerupuk sagu, kerajinan peci/kopiah, madu lebah, kue pia, dodol tapai, tenun songket, miniature jalur, jalur snack, aneka jamu instan, gelamai, kerajinan batik, kerajinan kayu zahara, kerajinan bamboo, dan berbagai usaha dagang lainnya.

Pemerintah Kabupaten Kuantan Singingi, pada era ekonomi asean saat ini sedang giat melaksanakan program peningkatan kualitas SDM para pelaku usaha, agar dapat bersaing dengan ekonomi global tersebut. Oleh karenanya, menurut Dinas Perindustrian, pemberdayaan masyarakat pelaku UKM, pemberdayaan sosial dan pemberdayaan lingkungan yang nyaman dan asri, merupakan program dan kegiatan yang diprioritaskan.Dinas Perindustrian juga mengungkapkan bahwa dalam rangka pengembangan UKM di Kabupaten ini, hal yang sangat penting dalam mengelola usaha adalah manajemen laporan keuangan yang 
harus tercatat dan terkelola dengan baik. Namun, hal ini menjadi kendala bagi para pelaku usaha, karena banyaknya keterbatasan seperti informasi, ilmu, fasilitator pelatihan, dan keterbatasan pendidikan. Maka, berdasarkan survey awal, tim menemukan bahwa pelatihan manajemen keuangan sederhana adalah solusi yang tepat untuk mengatasi permasalahan UKM dalam upaya pengembangan UKM di Kabupaten Kuantan Singingi.

Potensi UKM hingga sejauh ini, belum cukup tergarap dengan maksimal, sebaliknya banyak pelaku kegiatan UKM (pemilik) justru sering mengalami masalah internal sehingga sulit untuk berkembang dan bersaing baik antara sesama UKM maupun dengan produsen besar. Masalah pengelolaan keuangan merupakan salah satu masalah yang sering ditemui di dalam UKM. Umumnya, pelaku kegiatan ini memulai usaha mereka dengan bermodal nekat tanpa dibekali dengan rencana pemodalan jangka panjang maupun kemampuan dan pengetahuan manajerial yang dibutuhkan dalam berwirausaha. Beberapa masalah pengelolaan keuangan umum yang sering dijumpai pada UKM antara lain adalah: (1). Masih tercampurnya keuangan pribadi pemilik dengan keuangan usaha. (2). Penentuan harga produk sering dilakukan secara sederhana dan intuitif, tanpa menghitung biaya yang telah dikeluarkan secara cermat. (3). Buruknya metode pencatatan transaksi yang dilakukan dan (4). Kurangnya pengetahuan mengenai pencatatan keuangan dan pengelolaan keuangan (akuntansi).

Laporan keuangan merupakan salah satu sarana penting untuk mengkomunikasikan informasi kepada pihak-pihak diluar perusahaan. Eseni laporan keuangan sangat penting mengingat laporan keuangan memiliki keputusan penting mengenai kelangsungan hidup dan entitas bisnis (Pongoh, 2013). Didalam Statement of Financial Accounting Concepts (SFAC) No.1 juga menjelaskan bahwa tujuan utama dari laporan keuangan adalah untuk menyediakan informasi yang berguna dalam pembuatan keputusan bisnis dan ekonomi. Agar dapat memberikan informasi yang berguna maka laporan keuangan harus berkualitas. Menyediakan laporan keuanan berkualitas tinggi adalah penting karena hal tersebut akan secara positif mempengaruhi penyedia modal dan pemegang kepentingan lainnya dalam membuat keputusan investasi, kredit dan keputusan alokasi sumber daya lainnya yang akan meningkatkan efisiensi pasar secara keseluruhan.

Menurut Fahmi (2012), laporan keuangan sangat diperlukan untuk mengukur hasil usaha dan perkembangan perusahaan dari waktu ke waktu dan untuk mengetahui sudah sejauh mana perusahaan mencapai tujuannya. Laporan keuangan pada dasarnya merupakan hasil proses akuntansi yang dapat digunakan sebagai alat komunikasi antara data ekeuangan atau aktifitas suatu perusahaan dengan pihak - pihak yang berkepentingan dengan data atau aktivitas perusahaan tersebut. Sehingga laporan keuangan memegang peranan yang luas dan mempunyai suatu posisi yang mempengaruhi dalam pengambilan keputusan.

Berdasarkan teori tersebut diatas, maka penulis mengajukan program pengabdian masyarakat dalam rangka pelatihan laporan keuangan sederhana kepada UKM di Kecamatan Kuansing dengan metode pelatihan berupa pemberian materi dan Pratik pembuatan laporan keuangan sehingga nantinya pelaku UKM dapa mengatr dan mengelola keuangannya sebaik mungkin.

Sehubungan dengan beberapa hal diatas, maka kami tertarik untuk melaksanakan Kegiatan Pengabdian Kepada Masyarakat ini, dengan judul: Pelatihan Pembuatan Laporan Keuangan Bagi Industri UMKM di Kecamatan Benai, Kabupaten Kuantan Singingi, Provinsi Riau.

\section{MASALAH}

Masalah pengelolaan keuangan merupakan salah satu masalah yang sering ditemui di dalam UKM. Umumnya, pelaku kegiatan UKM memulai usaha mereka dengan bermodal nekat tanpa dibekali dengan rencana pemodalan jangka panjang maupun kemampuan dan pengetahuan manajerial yang dibutuhkan dalam berwirausaha. Perencanaan keuangan pada UKM ini masih lemah, pencatatan adminitrasi keuangan tidak tertib, dan akhirnya tidak dapat menghitung secara tepat dan benar berapa uang masuk serta uang keluar dalam berusaha, yang berakibat tidak bisa menghitung kerugian atau keuntungan secara tepat. Maka perumusan masalah dalam Pengabdian ini adalah: Bagaimanakah manajemen keuangan dari para UKM ini, dan bagaimana solusinya dalam mengatasi permasalahan didalam manajemen keuangan? 


\section{METODE}

Metode yang digunakan dalam kegiatan pengabdian ini adalah:

1. Penyampaian materi dengan cara memberikan ceramah, tanya jawab dan diskusi tentang permasalahan keuangan yang dihadapi oleh para pelaku usaha kecil dan mikro ini. Materi yang disampaikan berupa pengelolaan manajemen keuangan sederhana, pentingnya mengelola laporan keuangan, praktik mengelola laporan keuangan sederhana yang terdiri dari buku kas, buku utang, buku piutang, buku persediaan, neraca dan laporan laba rugi.

2. Memberikan contoh-contoh administrasi keuangan yang harus dipersiapkan didalam melakukan berbagai usaha.

3. Menyusun perencanaan keuangan, membukukannya serta membuat laporan keuangan dari usaha masing-masing pelaku UKM tersebut.

\section{PEMBAHASAN}

Potensi masyarakat dalam pengabdian ini dilihat dari pelaku usaha yang berada di Kabupaten Kuantan Singingi. Terdapat 32 orang pelaku UKM di Kecamatan Benai, Kabupaten Kuantan Singingi yang merupakan perwakilan dari masing - masing Desa. Peserta pengabdian ini terdiri dari pelaku usaha UKM dibidang perdagangan kuliner berjumlah 14 orang, bidang perdagangan kebutuhan rumah tangga 12 orang dan bidang usaha lain - lain 4 orang. Usaha yang dijalankan oleh peserta pengabdian pada awalnya hanya sebagai sampingan usaha saja, namun saat ini peserta mengaharapkan adanya pengembangan usaha agar tidak stagnan dan dapat berkembang.

Kegiatan pengabdian ini memperoleh informasi berdasarkan formulir identitas para peserta kegiatan yang menggambarkan tentang umur, status perkawinan, pendidikan terakhir, jenis usaha yang dijalankan, pendapatan perbulan, jumlah karyawan yang dimiliki, kendala atau hambatan usaha, modal usaha, pinjaman modal, pesaing, dan sebagainya.

Diketahui bahwa pendapatan rata - rata pelaku usaha hanya berkisar Rp 1.000.000 - Rp 2.000.000 setiap bulannya, dengan rata -rata jenis usaha yang dijalankan adalah gula aren. 85\% pelaku usaha juga tidak menggunakan modal usaha hanya menggunakan modal yang bersumber dari keluarga. Diketahui juga permasalahan atau hambatan yang terjadi adalah tidak adanya pengelolaan laporan keuangan sehingga perputaran modal tidak jelas dan omset yang diperoleh pelaku usaha selalu berampur dengan kebutuhan harian rumah tangga.

Permasalahan yang dihadapi masyarakat berkaitan dan sesuai dengan tujuan program pengabdian yang dijalankan yaitu manajemen laporan keuangan sederhana pada usaha UKM di Kecamatan Benai, Kabupaten Kuantan Singingi agar usaha masyarakat dapat lebih tertata laporan keuangannya dan dapat mengembangkan usaha yang dimiliki saat ini.

Menurut Fahmi (2012), laporan keuangan sangat diperlukan untuk mengukur hasil usaha dan perkembangan perusahaan dari waktu ke waktu dan untuk mengetahui sudah sejauh mana perusahaan mencapai tujuannya. Laporan keuangan pada dasarnya merupakan hasil proses akuntansi yang dapat digunakan sebagai alat komunikasi antara data keuangan atau aktifitas suatu perusahaan dengan pihak - pihak yang berkepentingan dengan data atau aktivitas perusahaan tersebut. Sehingga laporan keuangan memegang peranan yang luas dan mempunyai suatu posisi yang mempengaruhi dalam pengambilan keputusan.

Maka, dengan demikian, sangat jelas bahwa hal yang menjadi solusi permsalahan perkembangan usaha masyarakat adalam pengelolaan laporan keuangan usaha. Kegiatan pengabdian ini menyampaikan materi mengenai pentingnya memahami laporan keuangan, tujuan dan manfaat laporan keuangan bagi sebuah usaha, memberikan pengetahuan mengenai kiat - kiat dalam menyusun laporan keuangan agar dapat meningkatan usaha dan pendapatan dan melakukan praktik langsung untuk mengisi kertas kerja laporan keuangan usaha yang dimiliki oleh masyarakat. Dalam hal ini masyarakat memahami bagaimana cara mengisi buku kas, buku utang, buku piutang, buku persediaan, neraca, dan laporan laba rugi.

Masyarakat sebagai pelaku UKM sangat antusias dengan kegiatan pengabdian ini, karena hal ini dirasakan sangat penting bagi keberlangsungan usaha yang dijalankan agar dapat berkembang, dan dapat meningkatkan pendapatan masyarakat. Dalam pelatihan ini pemateri mensimulasikan pengerjaan laporan keuangan dengan memberikan asumsi kepada pelaku UKM untuk menggambarkan laporan keuangan berupa pengeluaran dan pendapatan secara sederhana dalam 1 minggu terakhir dan kemudian asumsi angka tersebut dihitung dan disimulasikan ke dalam kertas kerja yang terlah disediakan pemateri. Berdasarkan hasil praktikum yang dikumpulkan kembali sebagai bentuk evaluasi pelatihan, dapat dilihat bahwa $85 \%$ masyarakat dapat 
memahami materi yang disampaikan. Sedangkan 15\% lagi agak sedikit sulit memahami dan menerapkan karena permsalahan Pendidikan dan usia yang sudah manula. Pelaku UKM menujukkan antusiasme yang besar dan berusaha agar dapat mempraktikkan langsung berdasarkan materi dan kertas kerja yang telah diberikan, dan besar sekali minat masyarakat untuk dapat menerapkan kedalam usaha yang dijalankan saat ini.

Pengabdian ini juga dihadiri dan didampingi oleh mahasiswa Administrasi Bisnis yang sedang Kukerta di Kecamatan Kuantan Singingi. Masyarakat juga diajarkan dan didampingi langsung oleh 4 orang mahasiswa. Pengabdian tidak hanya dilakukan pada sekali waktu saja, namun tetap dilakukan pendampingan secara berkelanjutan melalui grup whatsapp yang telah dibentuk dan pemberian nomor handpone pemateri, dan juga pendampingan secara berkala yang dilakukan oleh mahasiswa Kukerta, sehingga pemateri dan tim pengabdian dapat memonitor sejauh mana kelayakan laporan keuangan yang sudah dibuat oleh pelaku UKM, dan bila pelaku UKM memiliki pertanyaan mengenai laporan keuangan, juga dapat menghubungi pemateri pada suatu waktu.
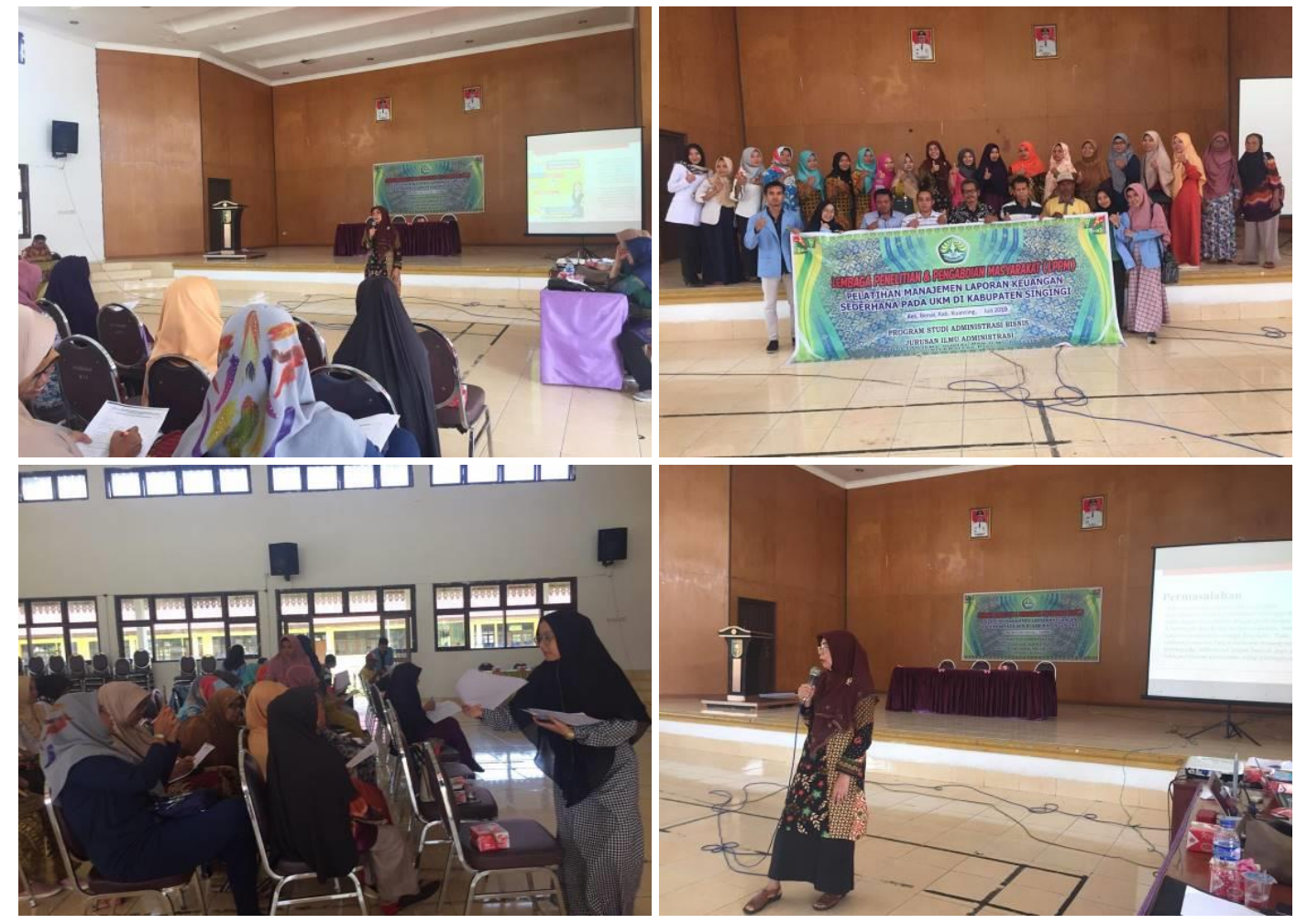

Gambar 1. Dokumentasi kegiatan pengabdian yang dilakukan pada bulan Juli tahun 2019 di Kecamatan Benai, Kabupaten Kuantan Singingi

\section{KESIMPULAN}

Kegiatan Pengabdian Kepada Masyarakat dengan judul "Pelatihan Pembuatan Laporan Keuangan pada UKM, Kabupaten Kuantan Singingi" diperoleh kesimpulan bahwa minat mereka sangat tinggi dalam mengelola keuangan dan melakukan pencatatan keuangan serta membuat laporan keuangan sehingga dapat menghitung keuntungan dengan benar dan akan memotivasi pelaku usaha untuk melakukan pengembangan usaha dan semangat para pelaku UKM ini sangat tinggi. Materi yang disampaikan tentang manajemen keuangan dan penyusunan laporan keuangan sederhana dirasakan sangat bermanfaat dan menjadi bekal dalam pengembangan usaha serta peningkatan pendapatan dari hasil usaha mereka. Mereka berharap penyuluhan, pelatihan dan pembinaan terhadap para pelaku UMKM ini lebih sering dilakukan.

Adapun saran berdasarkan kegiatan pengabdian ini adalah adanya pelatihan dan pendampingan yang dilakukan secara berkala dan adanya kolaborasi antara bakademisi, praktisi dan pemerintah agar dapat menjadikan usaha yang dimiliki masyarakat memiliki kontribusi dalam peningkatan perekonomian dan kesejahteraan masyarakat. 


\section{DAFTAR PUSTAKA}

Allen, D. 2004. Keputusan Keuangan Strategis. Jakarta: PT Pustaka Binaman Pressindo.

Amirullah, dkk. 2004. Pengantar Manajemen. Yogyakarta: Graha Ilmu.

Djahidin, E. F. 2005. Analisa Laporan Keuangan. Jakarta: Balai Aksara.

Fahmi, I. 2012. Analisis Kinerja Keuangan. Bandung: Alfabeta.

Gitosudarmo, I. 2008. Manajemen Keuangan. Yogyakarta: BPFE UGM.

Handoko, H. 2005. Manajemen. Yogyakarta: BPSE.

Martin, J. D., J. W. Petty. 2009. Dasar-dasar Manajemen Keuangan. Jakarta: PT Raja Grafindo Persada.

Munawir. 2005. Analisa Laporan Keuangan. Jakarta: PT Gramedia Pustaka Utama.

Pungoh, M. Analisis Laporan Keuangan untuk Menilai Kinerja Keuangan PT Bumi Resource, Tbk. Jurnal FEB, AKuntansi.

Sawir, A. 2006. Analisis Kinerja Keuangan dan Perencanaan Keuangan Perusahaan. Jakarta: PT Gramedia Pustaka Utama.

Sigit, S, 2003. Asas-Asas Akutansi. Yogyakarta: BPFE UGM.

Suryo, A. 2006. Akutansi untuk UKM. Yogyakarta: Media Pressindo.

Vinci, M. 2009. Manajemen Bisnis Eceran. Jakarta: Sinar Baru Algesindo.

Wibowo, S. 2006. Pedoman Pengelola Perusahaan Kecil. Bogor: PT Penebar Swadaya. 